http://ijeds.ppj.unp.ac.id/index.php/IJEDS

\title{
APPLYING COOPERATIVE LEARNING TO IMPROVE STUDENTS' ACTIVENESS IN WRITING DESCRIPTIVE TEXT
}

\author{
* Efriyenty, ${ }^{1}$ Hermawati Syarif, ${ }^{2}$ Yenni Rozimela ${ }^{3}$ \\ ${ }^{1}$ Student of English Education of Graduate Program, Universitas Negeri Padang \\ ${ }^{2}$ Lecturer of English Education of Graduate Program, Universitas Negeri Padang \\ ${ }^{3}$ Lecturer of English Education of Graduate Program, Universitas Negeri Padang \\ Email: efriyentyhanan@gmail.com
}

*Corresponding Author, Received: March 10, 2020, Revised: May 17, 2020, Accepted: June 10, 2020

\begin{abstract}
The aim of the research were to explain how cooperative learning improved student's activeness and the factors influence students' activeness in writing descriptive text at the grade VII students of SMPN 8 Padang. The research was Classroom Action Research. The data were collected through observation, field note, writing task and test score. The students were asked to decribe people by giving outline and describe animals based on the pictures given. The finding showed that (1) Cooperative Learning improved students' activeness in writing Descriptive Text. It was really effective in motivating and encouraging students to be actively involved in teaching and learning process.(2) This research also revealed that there were two factors inluence students' activenes. The factors involve teacher personal aproach and teacher motivation.
\end{abstract}

Keywords: Cooperative Learning, Activeness, Descriptive Text

\section{INTRODUCTION}

Writing is one of English skills that should be developed by the students at Junior High school. In the implementation of 2013 curriculum, one of the objectives of teaching English is to develop the abilities of students to make them to write or create a simple text. Moreover, in learning language processes, the curriculum provides Scientific Approaches as the steps in learning process. They consist of observing, questioning, experimenting, analyzing and communicating. The curriculum also states that the teacher is expected to apply experiential learning and provide challenges to achieve required progress. She is suggested to relate materials with students' abilities and interests. She also has to be able to motivate students to be independent learners. Then, she should train students how to work either in big groups or 
http://ijeds.ppj.unp.ac.id/index.php/IJEDS

small groups and create conductive physical and psychological environment to support students' development.

Getting students' focus, motivation, and on task during the process of the lesson, eventhough they could do the task well but they seemed lazy to do it. And lack of activeness in responding any activities assigned by the teacher are the problems in teaching writing descriptive text in that school. Creating a challenging and meaningful activity is needed to improve the learners to become more active. Furthermore, 2013 curriculum also facilitate the teachers as facilitator in the classroom and let students find the concept of materials by themselves in group activities. So, cooperative learning strategy is expected to solve those problems. There are some reasons why the reseacher choose cooperative learning. First, cooperative learning can motivate individual student learning. The students will learn how to think critically to achieve a given task. Cooperative learning also help students develop skills in oral communication (Slavin, 1995). In addition, cooperative learning is a teaching method that offers the opportunity for groups to work interdependently and get feedback from others (Jacobs \& McCafferty, 2006).

\section{METHOD}

This research was Classroom Action Research ( CAR ). The research was conducted at grade VII D of SMP N 8 Padang academic year 2014/2015. This research was conducted in two cycles. Each cycles consisted of four phases, namely ; plan, action, observation, and reflection. In every cycle consisted of three meetings. The time for each meeting was 80 minutes ( $2 \times 40)$ minutes. The result of each cycle was used as recommendation to make changes and improvement for the next cycle or kept doing the activities like the previous cycle. The recommendations could be found in the reflection stage of each cycle. The key instrument of the research was the researcher herself as a teacher who involed in every cycle. She used observation, questionaire, field notes, task and test.

\section{RESULTS AND DISCUSSION}

The actions in cycle 1 was conducted in three meetings which consist of two meetings were used for teaching and learning in the classroom while the third meeting was used for test. Based on the calculation, the average score of the students' score is 74.4. This result cannot be 
http://ijeds.ppj.unp.ac.id/index.php/IJEDS

interpreted as a good result or good achievement because the minimum score requirement or the average score that the students need to achieve is 80 . At the end of the meeting each student evaluate themselves about their activeness. They had to complete the table and the result of student's activeness in cycle 1 can be illustrated in grafic below.

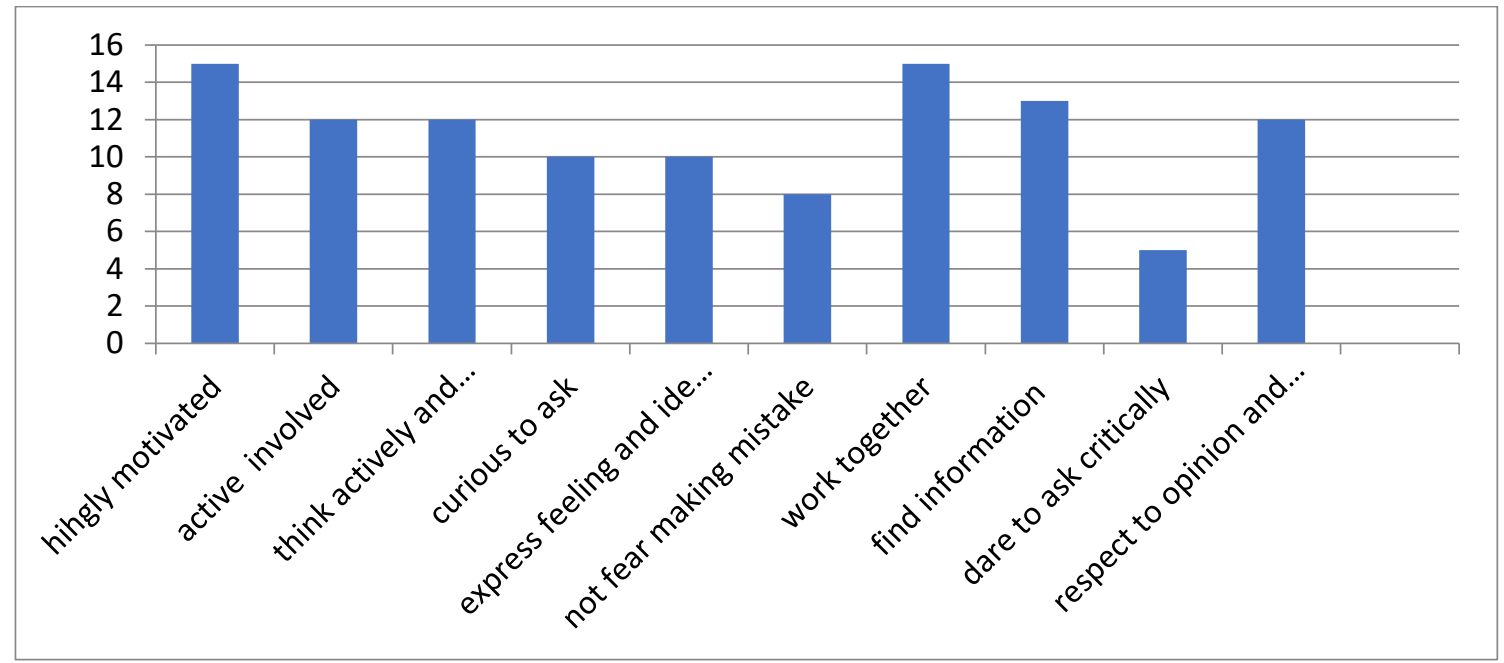

Based on data from the grafic, it could be concluded that the students had highly motivated and liked work together or in group. However, they were not active involved. They were also not curious and not dare to ask critically because most of them were fear to make mistake. In the second cycle, students' activeness improved significantly. It could be seen when they guessed the name of the animals. They were motivated to guess the correct one. The lower achiever students tried to participate. The percentage of the students in each activity were getting higher comparing with the first cycle. From the table, the teacher got the data that most of the students had highly motivated in learning (83\%). In learning activities, the students who active involved, think actively and creatively increased significantly. It found that 20 ( $67 \%$ ) students active involved, thing actively and creatively.

The number of students who curious to ask increased from 10 to 19 students (63\%) . It means that the materials make them ask . In expressing ideas and feeling orally, there were 20 students or $67 \%$ did so. Most of them were not fear to make mistake anymore. The data showed that there were 17 students ( $56 \%$ ) felt so. Furtheremore all of the students liked to work together. The activity encouraged themselves to generate and arrange the idea about descriptive text easily. The data informed that 27 students (90\%) enjoyed the group work. The persentage of students who dare in asking critically also improved $77 \%$. They were also active 
http://ijeds.ppj.unp.ac.id/index.php/IJEDS

in finding information and data. When the other groups displayed their work, about 26 students $(87 \%)$ respected to opinion and their friends' work. The grafic of improvement of students' activeness can bee seen as follow:

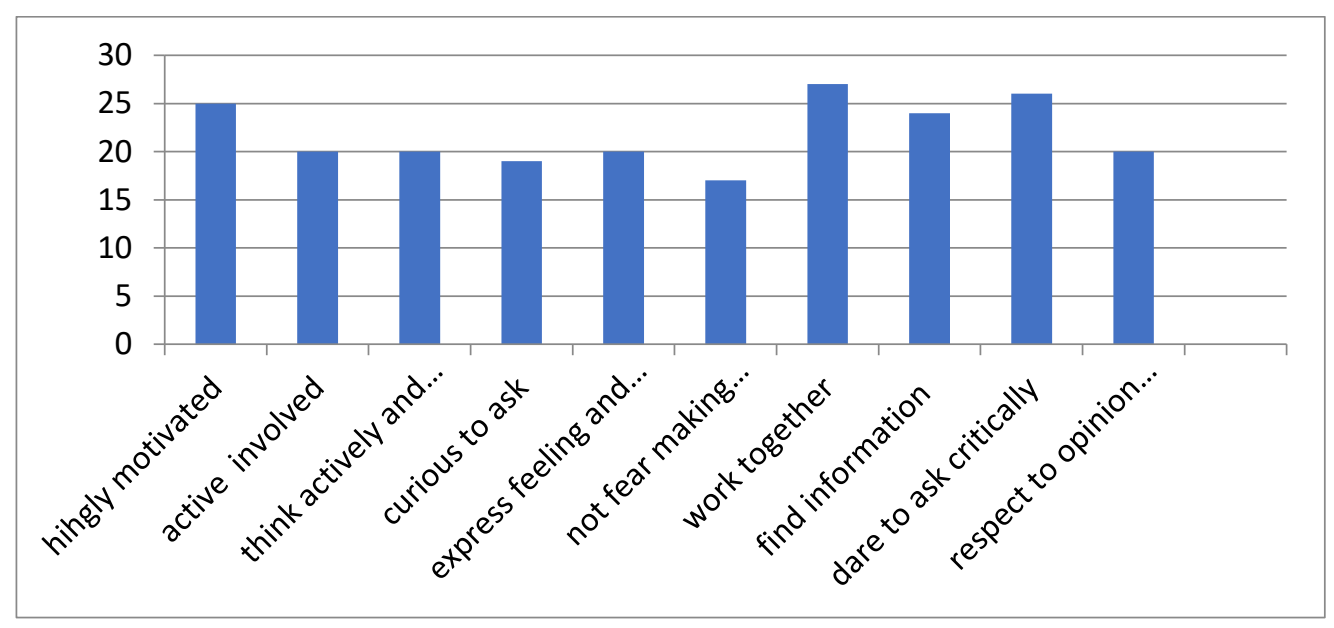

In the second cycle, the students' average score was 80.13 . The score significantly improved comparing with the first cycle. It increased 5.73. The result achieved the MAC -80 . Based on the result of students' observation and students score on writing test in the second cycle, it was found that students interested toward cooperative learning and most of them got high performance on score in writing test. In general, students' ability in writing descriptive text improved and cooperative learning could improve students' activeness.

Table 1. Comparison Students' Activenes During Cycle 1-2

\begin{tabular}{|c|c|c|c|}
\hline No & Description & Cycle1 & Cycle 2 \\
\hline 1. & Highly motivated & $50 \%$ & $83 \%$ \\
\hline 2 & Actively involved in learning activities & $40 \%$ & $67 \%$ \\
\hline 3 & Think actively and creatively. & $40 \%$ & $67 \%$ \\
\hline 4 & Curios to ask & $33 \%$ & $63 \%$ \\
\hline 5 & Express ideas and feelings orally & $33 \%$ & $63 \%$ \\
\hline 6 & Not fear making mistakes. & $28 \%$ & $56 \%$ \\
\hline 7 & Work together to develop social skills & $50 \%$ & $90 \%$ \\
\hline 8 & Find information, data, and seek answers to questions. & $43 \%$ & $80 \%$ \\
\hline 9 & Dared to ask critical & $17 \%$ & $77 \%$ \\
\hline 10 & Respect the opinions and friend's work. & $40 \%$ & $87 \%$ \\
\hline
\end{tabular}

Table 2. Comparison Students Score in writing Descriptive text

\begin{tabular}{|l|l|c|c|}
\hline & Aspects of writing & Cycle1 & Cycle 2 \\
\hline 1 & Fluentcy & 3.43 & 3.83 \\
\hline 2 & Grammar & 3.66 & 3.96 \\
\hline 3 & Vocabulary & 3.6 & 4.07 \\
\hline 4 & Content & 3.8 & 4.00 \\
\hline 5 & Spelling & 4.1 & 4.11 \\
\hline
\end{tabular}


http://ijeds.ppj.unp.ac.id/index.php/IJEDS

With reference to the finding of this research, it could be concluded that cooperative learning could improve the students' activenes in writing descriptive text at grade VII D at SMP N 8 Padang. Meanwhile, cooperative learning is really effective in motivating and encouraging students to be actively involved in teaching and learning process. However, the researcher found some aspects inluence the implementation of cooperative learning in improving students' activeness in writing descriptive text.

First, individual differences of students. Different students have displayed cooperative behaviors during times. One always eager to help someone in the group. However some students need remainding that the task is to cooperate with groupmate. The teacher should make it clear to the students. This fact supported by Mc Cafferty ( 2006 ) that learners differ from one another in term of intelligences and learning styles. The teacher is expected to shape these diffrences by giving instruction or task that students prefer to learn and remainding them to recognize, understand the diversity among the students.

The second factor was formating group. The researcher changed the group in the second cycle because she found that the students did not find their excitement, cooperation and fun during did the task. Mc Cafferty ( 2006 ) states that students who are unfamiliar with cooperative learning may need learn more the new format for learning. The researcher found difficulties to decide which students to be in a group, and how long they should in the same group. One effective way to get students to cooperative better is to provide extra reward to the winning team or the best team.

The next factor was the group activities. The researcher had experience that the students did not participate actively in doing the task. This condition was found in the first cycle.As Johnson (2005) puts it, cooperation is not assigning a job to a group of students where one student does all the work and the others put their names on the paper. It is not having students sit side by side at the same table to talk with each other as they do their individual assignments as well. It is not having students do a task individually with instructions that the ones who finish first are to help the slower students.

On the contrary, cooperative learning is a teaching strategy in which small teams, each with students of different levels of ability, use a variety of learning activities to improve their understanding of a subject. Each member of a team is responsible not only for learning what is taught but also for helping teammates learn, thus creating an atmosphere of achievement. Students work through the assignment until all group members successfully understand and 
http://ijeds.ppj.unp.ac.id/index.php/IJEDS

complete it. In the above part, the researcher admitted that she did not give variety of learning activities in the first cycle. The students had to describe people based on the outline from her. She did not let their students based on their interest like describing idol.

This research also revealed that there were two factors inluence students' activenes. The factors involve teacher personal aproach and teacher motivation. Teacher personal approache influenced the students activenes because the students would be enjoyable, motivated and not worried in learning especially in discussing. The slow leaners would not fear sharing if their friends and the teacher care of him or her. Therefore that it was hoped that every students could give contribution to the group work. Motivation from the teacher could improve students' activenes in writing descriptive test. One effective way to get students to cooperative and active better is to provide extra reward to the winning team or the best team. The students would happy and enjoy in learning. Nation (2001 ) suggests that positive feedback to learners can improve their attitude in writing.

Basically, cooperative learning is an old strategy done by the teachers long time ago. The teacher has allowed their students to work together on occasional group projects, group discussion or debate. Meanwhile, according to Slavin ( 1995 ) cooperative learning refers to a variety of teaching methods in which students work in small groups to help one another learn academic content. In cooperative classrooms, students are expected to help each other, to discuss and argue with each other, to assess each other's current knowledge and fill in gaps in each other's understanding. He adds that all cooperative learning share the idea that students work together to learn and are resposibilities for their teammates. The students emphasize the use of team goals and team success.

According to Kagan (1997) the first cooperative learning components is positive interdependence, the perception among the group members that what helps one group member helps all group members. In other word, positive interdependence encourages cooperation and a feeling of support. Next component is collaborative skills. In this component, the students feel that they learn more when they study in group. The third element is processing group interaction. It is about identifying which behavior of the members benefit to the success of the group, and also which behaviors should continue and which ones should be modified. It also refers to the assessment of cooperative learning. It can be described as a formative assessment that focuses on students' feedback on the learning process. The last is individual accountability. It means that group success depends on the learning of each and every individual. Every learner has the responsibility to learn the subject and do whatever must be done. 
http://ijeds.ppj.unp.ac.id/index.php/IJEDS

Furthermore, Mc Cafferty, Jacob and Christina (2006) only state two crucial concepts - positive interdependence and individual accountability. Both of them are the two concepts that make cooperative learning activities different from just putting students in group and asking them to work together. According to them, in positive interdependence, the group should share a goal or goals. Then, reward is needed to motivate students to study hard and to help others as well as to develop their collaborative skills. Furthermore, each group member has a role to play in helping the group achieve its goals. The role include facilitator, observer of collaborative skills, scibe or time keeper. . Role should rotate so that each student has opportunities to develop their care about the group. Next, each group is suggested having its identity to heighten group unity. For instance, students can invent a group name, create a group motto or probably a group flag. At last, group member have to do their best for the group when they compete againt other groups.

For teaching writing, Legenhausen and Wolff (1990) in Syafini concur that writing in small groups is an efficient way to promote writing abilities and it is an excellent interaction activity. Moreover, collaborative work between learners is encouraged to increase motivation and develop positive attitudes towards the writing activities (Nunan 1991). Their views are supported by a study conducted by Kagan and High (2002) which showed that students perform better in writing when cooperative learning is implemented in the classroom. It means that by writing in group will activate students' thinking skill and their creativity

Meanwhile, Harmer (2006) believes that writing in groups is effective in genre-based and proses approach. It can be a supplement to both of approaches with its conception of positive interdependence, individual accountability, equal participation, simultaneous interaction and group processing. Students find the activity motivating in terms of the writing itself. They also find the activity to be motivating when they discuss on the topics, have peer evaluation and achieved the group ${ }^{\text {ee }}$ s goal or easily finish a class project. Cambridge dictionary defines activeness as feeling of energetic interest in a particular subject or activity and an eagerness to be involved in it . This definition is closely related to active learners definition that students is involved in more than listening especially in higher- order- thinking ((analysis, synthesis, evaluation).

Collins Dictionaries defines activeness in several meanings. First, activeness is the state of being busy and pleasantly occupied; having a lot of different interests and doing a lot of activities. Another meaning for activeness is physical energy, mental allernest . It also explains 
http://ijeds.ppj.unp.ac.id/index.php/IJEDS

that activeness is involment in a particular type of activity, moving, working and do something in a particular area and active participate in an activity. Juszko (2011) states that students' activeness is engaging students in an activity that will make them think and analyse the information being taught. Activeness may occur at every stage of the lesson, starting from getting the students engaged in the topic, through actively taking part in discovering language and rules, to free, active production.

Harmer (1998) has said that each students bring unique personality to the classroom. Some of them are willing to listen. Active students listen what's going on.-not just in the sense of paying attention, but in the terms of really listening to the English that being used, abseobed it up with eagerness and intelligent. Also, during the lesson active learners not only attentively listen to and do whatever the teacher instructs, but also express their own opinions. That is to discuss the topic with the teacher and among students. They must actively put forwards what they consider ambiguous or problematic so that the teacher can help solve their .problems. Furthermore, active learner must think actively and critically.

The others one are willing to do experiment without afraid of risk, try things out and see how it work. A willingness to ask questions is also a part of students activeness since asking questions is one part of a succesful learning equipment. At last, students' activeness can be seen from their willingness to accept correction. Active learners are prepared of being corrected if it is helps them. They are keen to get feedback from the teacher and act upon what they are told.. In conclusion, students' activeness in learning is represented in both individual and cooperative learning activities. The students are expected to get involved not only in individual activities but also in team and group work. Through cooperative learning, interaction will be enhanced and learners' proficiency can be promoted through interaction. They must feel relaxed and encouraged to participate in learning activities. Furthermore, in cooperative learning the student are given opportunity to revive and rewrite what they have written. It also provides the student with the opportunity of evaluating his or her own work. They demonstrate more confidence in writing and improve their activeness towards writing.

\section{CONCLUSION}

The research finding indicates that using cooperative learning technique in process of writing practice contributed to students' activeness. The reasons for this finding could be explained by many reasons. First of all, the composition of the cooperative learning groups 
http://ijeds.ppj.unp.ac.id/index.php/IJEDS

enabled students to write a better paragraph than working alone. They had opportunities to share and learn with their peers. Student-student interaction via working in small groups can maximize their learning. They were more confident to write because they could share their ideas and were not much worried about the mistakes. Second, cooperative learning creates a comfortable environment for learning and practicing English. Cooperative learning provides a less anxiety-of students in discussing, creating, and thinking in a group rather than in a whole class. A comfortable environment is useful for learning and practicing English. It helps students to have more fun in classroom. Third, in cooperative learning environment, students had a chance to generate, discuss, analyze and synthesize ideas to determine the answer for the group. In cooperative learning the student are given opportunity to write and to revive and rewrite what they have written. Peer criticism aids students sharpen their knowledge about essays structure and grammatical rules. In order to evaluate effectively someone else's papers students must know what to look for and be able to justify their comments. It also provides the student with the opportunity of evaluating his or her own work. They demonstrate more confidence in writing and decrease their apprehensions towards writing. Teaching through this would be equally interesting both for the teacher and the students. The students working with partners ask each other for help and improve their attitude towards writing. They will show high level of enthusiasm, curiosity and involvement in being taught through cooperative learning tasks. Thus, an incorporation of these activities will be of great benefit to the student community and help them enhance their writing skills.

\section{REFERENCES}

Cambridge Advance learners Dictionaries. Third edition. 2008. Collins English dictionaries. 2010

Harmer, Jeremy. 1998 . How to teach English. An intrduction to practice an English Language teaching. Wesley Longman Limited.

Harmer, J. 2006. The Practice of English Language Teaching. England: Pearson Education Limited.

Johnson, D.W.Johnson,R.T(2005). Cooperative Learning Method: A Meta Analysis. Retrieved January 2018 from www.clcrc.com/pages/cl-methods.html

Kagan, Spencer.1997.Cooperative Learning. A Source of Lesson Plans for Teacher Education on Cooperative Learning. Singapore. SEAMEO Regional Language Center

Mc Cafferty, Steven., M.Jacob,George., Idding, Anna Christina Dasilva (2006). Cooperative Learning and Second Language Teaching. New York: Cambridge University Press. 
http://ijeds.ppj.unp.ac.id/index.php/IJEDS

Nation, I.S.P. 2001. Teaching ESL/EFL. Reading and Writing. New York: Roudledge. Taylor \& Francis Group.

Slavin, Robert. E. 1995. Cooperative Learning:Theory, Research and Practice. Massachusette: Simon \& Schuster Company.

Syafini bt Ismail and Tengku Nur Rizan. 2000. The effects of cooperative learning in enhancing the writing performance of form one students in an urban school. Thesis. Universitas Kebangsaan Malaisya 